\title{
Estuaries and Coasts as an Outlet for Research in Coastal Ecosystems: A Bibliometric Study
}

\author{
James W. Fourqurean • Carlos M. Duarte • \\ Mark D. Kershaw $\cdot$ Stephen T. Threlkeld
}

Received: 28 December 2007 /Revised: 31 March 2008/Accepted: 31 March 2008/Published online: 25 April 2008

(C) Coastal and Estuarine Research Federation 2008

\begin{abstract}
Recent changes in the editorial leadership, name, content, and publishing process for Estuaries and Coasts and looming changes in scientific publishing as technology advances have provided an opportunity to assess the health and examine the growth in size and reputation of the journal. Estuaries and Coasts has grown in size by about fourfold, with a concurrent decline in acceptance rate of about $1.5 \%$ per year to reach the present $65 \%$ acceptance rate. The number of paper downloads has increased exponentially to the current 4,000 downloads per month. Most ( $81 \%)$ of the published papers come from senior authors in the USA, with only $15 \%$ of the papers coming from senior authors based in non-English-speaking countries. The average number of authors per paper increased from an average of two in 1980 to three at present, and the impact factor has risen to 1.563 in 2006, at about the middle of the range in impact factors for related journals, from an average of 1.295 in the previous 10 years. Papers published in Estuaries and Coasts have a long citation half-life (8.4 years), resulting in very few $(3.5 \%)$ published papers never receiving citations. All
\end{abstract}

J. W. Fourqurean $(\bowtie) \cdot$ M. D. Kershaw

Department of Biological Sciences and Southeast Environmental

Research Center, Florida International University,

Miami, FL 33199, USA

e-mail: jim.fourqurean@fiu.edu

C. M. Duarte

IMEDEA, CSIC-UIB,

Miquel Marqués 21,

07190 Esporles, Mallorca, Spain

S. T. Threlkeld

Department of Biology, University of Mississippi,

328 Shoemaker Hall,

University, MS 38677, USA metrics assessed portray Estuaries and Coasts as a journal on the rise that stands up in comparisons of quality and citation rate with other journals in its field.

Keywords Bibliometric analysis · History of the journal . Impact factor $\cdot$ Publication statistics

The journal Estuaries and Coasts started as Chesapeake Science in 1960, with an aim to provide an outlet for studies of the natural resources of the Chesapeake Bay watershed (Cronin 1960), and the first issue contained 13 short papers in 76 small pages $(17.5 \times 25.4 \mathrm{~cm}$, Fig. 1). Chesapeake Science was published by the Chesapeake Biological Laboratory of the University of Maryland, and all papers in the first volume of this eponymous journal reported on research from the upper reaches of the Chesapeake Bay. The iconic status of Chesapeake Bay as a model estuary attracted readership and interest beyond the mid-Atlantic North American home of the bay, and soon papers reporting on research conducted in other estuarine systems began to appear in what was envisioned by its first editors as a regional journal. By the time the last issue of Chesapeake Science was published 18 years later, fewer than half of the papers published reported on work in the Chesapeake Bay.

In 1977, Chesapeake Science was acquired by the Estuarine Research Federation; the name of the journal was changed to Estuaries, and the scope of the journal was broadened to incorporate research on any aspect of natural science applied to estuaries, with no geographical boundaries (Wiley 1978; Threlkeld 2006). This new journal retained at first the small page size and short article length of its progenitor. The broadening scope of the journal spurred rapid growth in the amount of research reported in Estuaries. In the late 1970s and early 1980s, the journal published roughly 50 papers a year in about 300 journal 


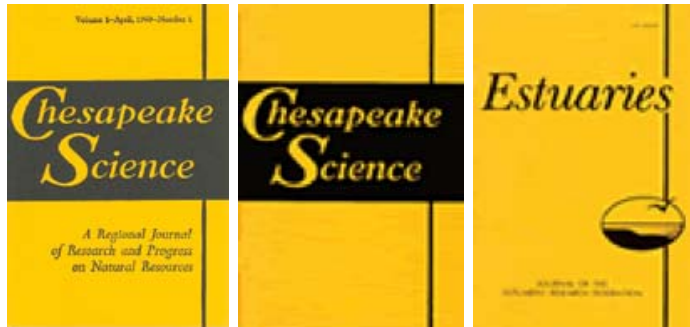

1960-1968 1968-1977 1977-1986

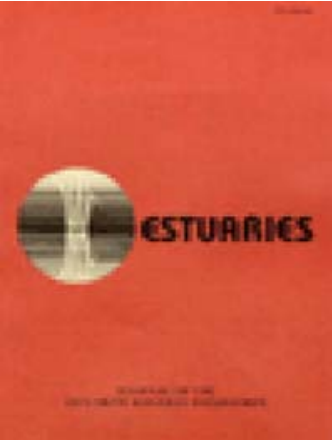

1987-2002

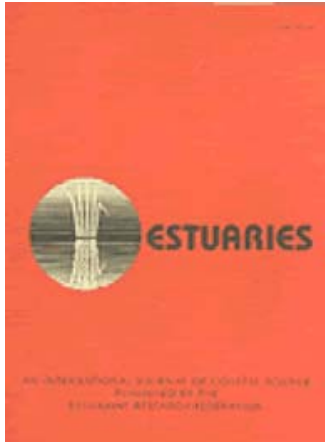

2003-2005

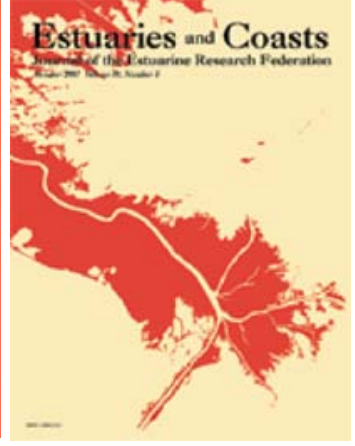

2006-

Fig. 1 Evolution of the face of the journal now known as Estuaries and Coasts

pages. The demand for space in the journal grew, and by 1987 , it became necessary to increase the page size (to the current $21.5 \times 28 \mathrm{~cm}$ ) to incorporate the growing number of longer papers being accepted for publication. In 2006, in an attempt to be more descriptive of the actual scope of research published in the journal and to explicitly encourage submissions from coastal regions of the world without classic drowned river valley estuaries, the name of the journal was changed to Estuaries and Coasts.

The number of pages published per year began a rapid increase from around 300 pages per year in the late 1980s to about 1,200 pages per year currently. Even with this increase in journal space, increasing demand for space outstripped the increase in capacity, so the acceptance rate of papers has been significantly declining $(p=0.05)$ at a rate of $1.5 \%$ per year, from around $80 \%$ in early 1990 s to around $65 \%$ currently. As first crude measures of the health of the journal, the large increase in volume of research reported in the journal and the increasing selectivity of the editorial process suggest competition for space in the journal is stiffening.

Increasing demand for the content of Estuaries and Coasts would also indicate that the journal is healthy. The journal's contents have been available electronically since 1999. The number of papers downloaded per month has roughly doubled each year since electronic access was initiated and is now over 4,000 papers per month or approximately 400 downloads, on average, per paper published. This huge increase in electronic access has apparently not had an impact on the size of the membership of the Coastal and Estuarine Research Foundation (CERF); CERF members receive the journal as one of the benefits of membership, and the continued growth of CERF indicates that electronic access to Estuaries and Coasts is not a disincentive to be a member of the Foundation. However, institutional subscriptions have declined (3.2\%) since 2003, a general trend observed in most professional journals due to increased campus-wide electronic access and budgetary reductions at academic libraries.
In an effort to understand the demographics of the coastal and estuarine science community that has been driving the increase in size and selectivity of the journal as well as to examine the relative strengths and weaknesses of the journal compared to other related publications, we conducted a bibliographic analysis of data compiled by the Thomson Corporation and published online in the ISI Web of Science ${ }^{\circledR}$ (http://portal.isiknowledge.com/portal.cgi). We limited our analysis to the time period 1992 through 2005 to correspond to the availability of data and the change in journal name to Estuaries and Coasts.

The corresponding authors of papers appearing in Estuaries between 1992 and 2005 hailed from 25 countries, although the large majority ( $81 \%$ of the 1,191 papers published) was from the USA (Table 1). There were 156 papers from European authors, 45 from non-US North American authors, 43 from Australia and New Zealand, 23 from South America, 19 from Asia, and 9 from Africa. This distribution can be partly attributed to the history of the journal's development in the USA, as well as the distribution of research institutions with an emphasis on research in coastal environments, research funding, estuarine habitats, and English-speaking authors. A total of 183 or $15 \%$ of the corresponding authors came from countries where English, the language of the journal, is not a national language.

Most of the papers appearing in Estuaries over the time period examined here came from corresponding authors associated with academic institutions, but a substantial number of the papers were produced by scientists affiliated with government agencies (Table 2). Perhaps as a consequence of the history of the journal as well as the large number of productive scientists at the institution, the University of Maryland was the most often listed affiliation, and Louisiana State University also contributed over 5\% of the papers published between 1992 and 2005. Scientists at governmental agencies contribute a significant number of papers to Estuaries; the US National Oceanic and Atmospheric Administration, Geological Survey, and Environ- 
Table 1 Country of origin of the corresponding author of the 1,191 papers published in Estuaries and Coasts in the period 1992-2005

\begin{tabular}{lrc}
\hline Country/territory & Record count & \% of 1191 \\
\hline USA & 967 & 81.2 \\
France & 38 & 3.2 \\
Australia & 35 & 2.9 \\
Canada & 34 & 2.9 \\
England & 20 & 1.7 \\
Denmark & 16 & 1.3 \\
Spain & 15 & 1.3 \\
Germany & 14 & 1.2 \\
Portugal & 13 & 1.1 \\
Sweden & 12 & 1.0 \\
Argentina & 11 & 0.9 \\
Mexico & 11 & 0.9 \\
Netherlands & 10 & 0.8 \\
Belgium & 9 & 0.8 \\
Brazil & 9 & 0.8 \\
Italy & 9 & 0.8 \\
Peoples Republic of China & 9 & 0.8 \\
South Africa & 9 & 0.8 \\
New Zealand & 8 & 0.7 \\
India & 5 & 0.4 \\
Scotland & 5 & 0.4 \\
Wales & 5 & 0.4 \\
Ireland & 4 & 0.3 \\
Taiwan & 4 & 0.3 \\
Chile & 3 & 0.3 \\
\hline
\end{tabular}

mental Protection Agency are all ranked in the top ten organizations that employ Estuaries authors.

The growth of the journal is a result of the combined efforts of many authors. From 1992 to 2005, 1,191 papers were published, with 2,530 different authors. A number of authors, however, have concentrated their publications in the journal. The top 22 authors, in terms of the number of papers they contributed to Estuaries, published 210 papers in the journal (Table 3). By far the most prolific author over the time interval has been Professor Kenneth W. Able of Rutgers University Marine Field Station; Dr. Able published 25 papers in Estuaries between 1992 and 2005, mostly on the ecology of estuarine fish communities.

There has been a steady increase in the number of authors per scientific paper since the journal's inception (Fig. 2). Similar patterns have been noted across the range of scientific publications (e.g., medicine, Zetterstrom 2004; psychology, Sacco and Milana 1984). In 1960, most papers in Chesapeake Science had single authors. By 1980, the average paper in Estuaries had two authors, and currently there are three authors per paper on average. The striking trend most likely is fueled by multiple factors. As our science becomes more specialized and interdisciplinary, larger teams are working together to tackle research projects. As the culture of scientific institutions has changed, it is likely that junior scientists who contribute substantially to scientific inquiry on teams are now more likely to get credit for their contributions in the form of authorship on papers.

The growth, in terms of numbers of papers submitted and published, of Estuaries and Coasts suggests that the journal has succeeded in the marketplace of scientific publishing. Other measures of the journal's health can be made by examining the citation statistics. One of the most often used gauges of journal strength is the Impact Factor (IF), computed by the Institute for Scientific Information (ISI). The IF for a given year is calculated as the total number of citations in that year to papers published in the previous 2 years divided by the number of papers published in those 2 years, i.e., $\mathrm{IF}_{2006}=$ [(citations in 2006 of papers published in Estuaries and Coasts in 2004)+(citations in 2006 of papers published in Estuaries and Coasts in 2005)]/[number of papers published in 2004 and 2005 in Estuaries and Coasts]. The IF is a useful, but not perfect,

Table 2 The institutions responsible for the most papers in Estuaries and Coasts during the period 1992-2005, as determined by the address of the corresponding author of the 1,191 papers published during the period

\begin{tabular}{|c|c|c|}
\hline Rank & Institutional Affiliation & $\begin{array}{l}\text { Number of } \\
\text { papers }\end{array}$ \\
\hline 1 & University of Maryland & 63 \\
\hline 2 & Louisiana State University & 61 \\
\hline 3 & Rutgers University & 56 \\
\hline 4 & $\begin{array}{l}\text { US National Oceanographic and } \\
\text { Atmospheric Administration }\end{array}$ & 53 \\
\hline 5 & US Geological Survey & 52 \\
\hline 6 & $\begin{array}{l}\text { College of William and Mary and/or Virginia } \\
\text { Institute of Marine Science }\end{array}$ & 44 \\
\hline 7 & US Environmental Protection Agency & 42 \\
\hline $\mathrm{t}-8$ & Texas A\&M University & 38 \\
\hline $\mathrm{t}-8$ & University of Washington & 38 \\
\hline 10 & University Rhode Island & 34 \\
\hline 11 & University North Carolina & 29 \\
\hline 12 & University Georgia & 26 \\
\hline 13 & State University of New York-Stony Brook & 23 \\
\hline 14 & University of Texas & 20 \\
\hline $\mathrm{t}-15$ & Marine Biological Laboratory & 19 \\
\hline $\mathrm{t}-15$ & University of Virginia & 19 \\
\hline $\mathrm{t}-17$ & University of Delaware & 18 \\
\hline $\mathrm{t}-17$ & University of South Carolina & 18 \\
\hline 19 & Old Dominion University & 17 \\
\hline 20 & Academy of Natural Sciences & 16 \\
\hline 21 & University of Florida & 16 \\
\hline 22 & Woods Hole Oceanographic Institute & 15 \\
\hline$t-23$ & East Carolina University & 14 \\
\hline$t-23$ & Florida International University & 14 \\
\hline $\mathrm{t}-23$ & Louisiana University Marine Consortium & 14 \\
\hline $\mathrm{t}-23$ & San Diego State University & 14 \\
\hline $\mathrm{t}-23$ & Skidaway Institute of Oceanography & 14 \\
\hline $\mathrm{t}-23$ & University of South Florida & 14 \\
\hline
\end{tabular}


Table 3 A list of the top 22 authors in Estuaries and Coasts during the period 1992-2005, by the number of papers each published during that interval

\begin{tabular}{llc}
\hline Rank & Author & Number of Papers \\
\hline 1 & Able, K.W. & 25 \\
2 & Turner, R.E. & 14 \\
3 & Day, J.W. & 13 \\
t-4 & Armstrong, D.A. & 10 \\
t-4 & Sanders, J.G. & 10 \\
t-4 & Zedler, J.B. & 10 \\
t-7 & Boynton, W.R. & 9 \\
t-7 & Fourqurean, J.W. & 9 \\
t-7 & Nixon, S.W. & 9 \\
t-7 & Stevenson, J.C. & 9 \\
t-7 & Zieman, J.C. & 9 \\
t-12 & Chambers, R.M. & 8 \\
t-12 & Christian, R.R. & 8 \\
t-12 & Montagna, P.A. & 8 \\
t-12 & Rabalais, N.N. & 8 \\
t-12 & Riedel, G.F. & 8 \\
t-12 & Simenstad, C.A. & 8 \\
t-18 & Cifuentes, L.A. & 7 \\
t-18 & Deegan, L.A. & 7 \\
t-18 & Houde, E.D. & 7 \\
t-18 & Jordan, T.E. & 7 \\
t-18 & Valiela, I. & 7 \\
\hline
\end{tabular}

These 22 authors published a total of 210 of the 1,191 papers or $18 \%$ of the papers

measure of the relative visibility of the papers in the journal compared to other journals about which much has been written (e.g. Turner 1994; Bordons et al. 2002). The most recent year for which IFs have been reported is 2006; the $\mathrm{IF}_{2006}$ for Estuaries and Coasts is 1.563 , significantly higher than the mean of the previous 10 years of $1.295 \pm$ 0.075 (95\% confidence interval).

Each journal indexed by the ISI is assigned to one or more subject categories; each subject category contains journals with related content. Estuaries and Coasts is included in two subject categories: Environmental Sciences and Marine and Freshwater Biology. Using only the IFs within a subject category to rank the journals within the category, Estuaries and Coasts ranks 50th out of 144 journals in Environmental Sciences and 26th out of 40 in Marine and Freshwater Biology.

Many of the individual papers published in Estuaries and Coasts during the period 1992-2005 have been highly influential on the field, judging by the number of citations they have received (Table 4). The most highly cited paper appearing in the journal over this interval was Professor Ivan Valiela and co-workers' paper (Valiela et al. 1992) demonstrating the water quality linkages between estuaries and their watersheds using Waquoit Bay as an example system, which has been cited over 200 times. Eight of the ten most highly cited papers published during the evaluation period came from special issues, prominently volume 15 , number 4 , on "Couplings between watersheds and coastal waters" which produced four of the ten top-cited papers.

We analyzed the available citation data to ascertain whether authors are submitting their best work to Estuaries and Coasts. We collected data on the publications of the top 50 authors as determined by the number of papers they published in Estuaries and Coasts. These 50 authors published 308 of the 1,191 papers published in Estuaries and Coasts during 1992-2005, and they also published many papers in other journals (Table 5). Estuaries and Coasts authors most often publish in Marine Ecology Progress Series, Limnology and Oceanography, and Estuarine, Coastal and Shelf Science. Papers published by the top 50 authors in Estuaries and Coasts are as visible, in terms of the citations they receive, as those published in the competing journals (Fig. 3), despite the higher impact factors of Marine Ecology Progress Series and Limnology and Oceanography.

The journals most cited by Estuaries and Coasts papers can be thought of as the most important sources of papers used to interpret information published in Estuaries and Coasts, while the journals that most often cite Estuaries and Coasts papers are the ones that rely most strongly on the information in Estuaries and Coasts to interpret papers published in those journals (Table 6). After normalizing by the relative number of papers in each journal, the journals most often cited by Estuaries and Coasts papers are Estuaries and Coasts itself, followed by Limnology and Oceanography, Aquatic Botany, and Marine EcologyProgress Series. There is asymmetry in the citations pattern to and from Estuaries and Coasts, and a different ranking of similarity is reached when looking at the journals whose

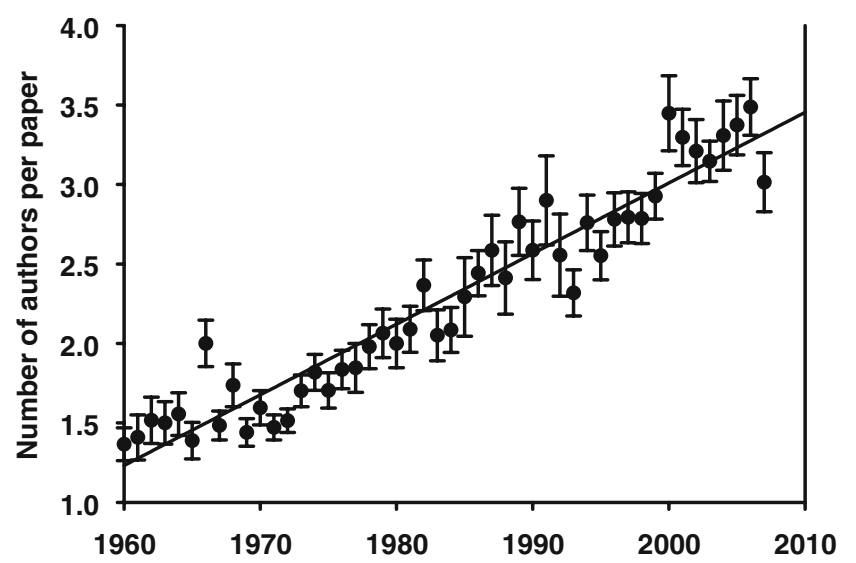

Fig. 2 The mean number of authors per paper ( \pm 1 standard error) as a function of the year of publication of papers in Chesapeake Science, Estuaries, and Estuaries and Coasts. The linear rate of increase (straight line) is 0.44 authors per decade 
Table 4 The ten most-cited papers in Estuaries and Coasts published between 1992 and 2005, based on citation data through 2005

\begin{tabular}{|c|c|}
\hline Number of citations & Paper \\
\hline 219 & $\begin{array}{l}\text { Valiela I, Foreman K, Lamontagne M, Hirsh, D., Costa, J., Peckol, P., Demeoandreson, B., Babione, M., Sham, C., } \\
\text { Brawley, J., and Lajtha, K. 1992. Couplings of watersheds and coastal waters-sources and consequences of nutrient } \\
\text { enrichment in Waquoit Bay, Massachusetts. Estuaries 15(4): 443-457 }\end{array}$ \\
\hline 174 & $\begin{array}{l}\text { Rabalais N.N., Wiseman W.J., Turner R.E., Sengupta, B. K., Dortch, Q. 1996. Nutrient changes in the Mississippi River } \\
\text { and system responses on the adjacent Continental Shelf. Estuaries 19(2b): 386-407 }\end{array}$ \\
\hline 152 & $\begin{array}{l}\text { Boynton W.R., Garber J.H., Summers R., Kemp, W.M. 1995. Inputs, transformations, and transport of nitrogen and } \\
\text { phosphorus in Chesapeake Bay and selected tributaries. Estuaries 18(1b): } 285-314\end{array}$ \\
\hline 145 & $\begin{array}{l}\text { Macintyre H.L., Geider R.J., Miller D.C. 1996. Microphytobenthos: the ecological role of the "Secret Garden" of } \\
\text { unvegetated, shallow-water marine habitats.1. distribution, abundance and primary production. Estuaries 19(2a): 186-201 }\end{array}$ \\
\hline 113 & $\begin{array}{l}\text { Sfriso A., Pavoni B., Marcomini A., Orio, A.A. 1992. Macroalgae, nutrient cycles, and pollutants in the Lagoon of } \\
\text { Venice. Estuaries 15(4): 517-528 }\end{array}$ \\
\hline 86 & $\begin{array}{l}\text { Correll D.L., Jordan T.E., Weller D.E. 1992. Nutrient flux in a landscape-effects of coastal land-use and terrestrial } \\
\text { community mosaic on nutrient transport to coastal waters. Estuaries 15(4): 431-442 }\end{array}$ \\
\hline 85 & $\begin{array}{l}\text { Rozas L.P., Minello T.J. 1997. Estimating densities of small fishes and decapod crustaceans in shallow estuarine habitats: } \\
\text { a review of sampling design with focus on gear selection. Estuaries 20(1): 199-213 }\end{array}$ \\
\hline 83 & $\begin{array}{l}\text { Monbet Y. 1992. Control of phytoplankton biomass in estuaries - a comparative-analysis of microtidal and macrotidal } \\
\text { estuaries. Estuaries 15(4): 563-571 }\end{array}$ \\
\hline 81 & $\begin{array}{l}\text { Weisberg S.B., Ranasinghe J.A., Schaffner L.C., Diaz RJ, Dauer DM, Frithsen JB. 1997. An estuarine Benthic Index of } \\
\text { Biotic Integrity (B-ibi) for Chesapeake Bay. Estuaries 20(1): 149-158 }\end{array}$ \\
\hline 81 & $\begin{array}{l}\text { Malone TC, Conley DJ, Fisher TR, Glibert PM, Harding LW, Sellner KG. 1996. Scales of nutrient-limited phytoplankton } \\
\text { productivity in Chesapeake Bay. Estuaries 19(2b): 371-385 }\end{array}$ \\
\hline
\end{tabular}

Table 5 Listed are the top 25 journals, by number of papers published, in which the Estuaries and Coasts author pool, as represented by the top 50 authors in Estuaries and Coasts, also published during the period 1992-2005
The top 50 authors, by number of papers published in Estuaries and Coasts, also published in other venues. These 50 authors published 308 of the 1,191 papers published in Estuaries and Coasts during 1992-2005.

$$
\text { Journal name }
$$

Number of papers published by top 50 Estuaries and Coasts authors

\begin{tabular}{lc}
\hline Marine Ecology-Progress Series & 138 \\
Limnology and Oceanography & 92 \\
Estuarine Coastal and Shelf Science & 62 \\
Biological Bulletin & 56 \\
Biogeochemistry & 47 \\
Journal of Experimental Marine Biology and & 38 \\
Ecology & \\
Marine Biology & 33 \\
Ecological Applications & 30 \\
Canadian Journal of Fisheries and Aquatic & 24 \\
Sciences & \\
Journal of Geophysical Research-Oceans & 24 \\
Bulletin of Marine Science & 23 \\
Fishery Bulletin-NOAA & 22 \\
Marine Chemistry & 22 \\
Continental Shelf Research & 21 \\
Hydrobiologia & 21 \\
Marine Pollution Bulletin & 21 \\
Aquatic Botany & 19 \\
Bioscience & 18 \\
Ecology & 17 \\
Journal of Environmental Quality & 17 \\
Wetlands & 16 \\
Environmental Science \& Technology & 15 \\
Journal of Coastal Research & 15 \\
Mournal of Plankton Research & 14 \\
Microbial Ecology & 14 \\
\hline &
\end{tabular}




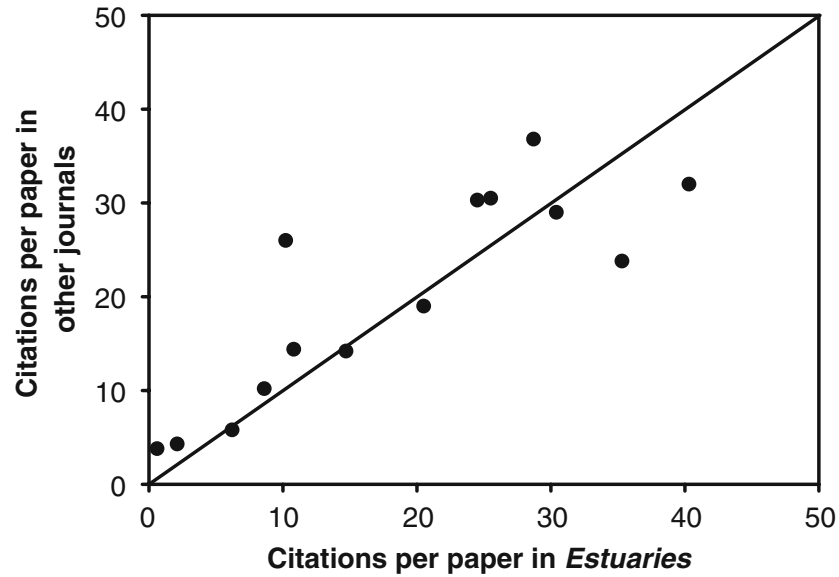

Fig. 3 The relationship between the annual mean (1992-2005) number of citations of the papers written by the 50 most prolific authors in Estuaries and Coasts and the mean number of citations of the papers published by these authors in other journals. The 1:1 ratio is indicated

papers most often cite Estuaries and Coasts papers. Estuaries and Coasts papers are the leading source of citations to Estuaries and Coasts, followed by Estuarine, Coastal and Shelf Science, Wetlands, and the Journal of Coastal Research.

Using $\mathrm{IF}_{2006}$ as a metric for comparison among the journals most related to Estuaries and Coasts (Table 6), Estuaries and Coasts $\left(\mathrm{IF}_{2006}=1.563\right)$ ranks near the middle of both the group of journals that most cite Estuaries and Coasts papers (range 0.665-3.287; median=1.672) as well as near the middle of the group of journals most often cited in Estuaries and Coasts papers (1.093-3.444; median= 1.675). Among these related journals, Oceanography and Marine Biology - an annual review has the highest impact factor (3.444 in 2006). The relatively high IF of this journal is to be expected, since it publishes lengthy, invited review papers. For the related journals that publish mostly original research, the journals Limnology and Oceanography, Biogeochemistry, and Marine Ecology-Progress Series have the highest $\mathrm{IF}_{2006}$ scores. The disciplinary and ecosystem scopes of these journals are much broader than those of Estuaries and Coasts; the broader scope is expected to broaden the readership and, therefore, the potential authors of papers that cite work in those journals.

Estuaries and Coasts has a decreasing, but still comparatively high, rate of acceptance of papers submitted for consideration for publication. In 2004 and 2005 (the publication dates of papers that contributed to the $\mathrm{IF}_{2006}$ ), the mean acceptance rate at Estuaries and Coasts was $49.2 \%$ (note that this is lower than the current acceptance rate of ca. $65 \%$ because acceptance rates were higher in both 2003 and 2006). Among the journals most closely related to Estuaries and Coasts, this rate of acceptance is higher than for papers submitted to Limnology and Oceanography (38.5\%), Aquatic Botany (32.4\%), or Wetlands (41.0\%); but less than the $55.0 \%$ acceptance rate for Marine Ecology Progress Series for the same period, yet the $\mathrm{IF}_{2006}$ for Estuaries and Coasts was intermediate between Aquatic Botany and Limnology and Oceanography (Fig. 4). This suggests that factors like the scope of the journal and the size of the readership may have a greater influence over the IF of a journal than the selectivity of the editorial process.

The IF assesses only how often the average paper in a journal gets cited within the first 2 years of its publication. The median age of papers appearing in Estuaries and Coasts that were cited in all journals in 2006 (i.e., the cited half-life computed by ISI) was 8.4 years-indicating that publications in the journal make lasting contributions to the field. In the case of Estuaries and Coasts, this simple halflife calculation is complicated by the fact that the number of papers published per year has been increasing through the history of the journal. Indeed, the rate of citation of Estuaries and Coasts papers increases for the first 4 years, as the papers are read and cited by scientists writing new papers, and then remains constant for at least 12 years following their publication (Fig. 5). The proportion of papers published in Estuaries and Coasts that were older than the half-life at the time of our search that were never

Table 6 The journals most related to Estuaries and Coasts, as reflected by patterns of citation among the journals

\begin{tabular}{cll}
\hline Rank & Journals most often cited by Estuaries and Coasts papers & Journals most frequently citing Estuaries and Coasts papers \\
\hline 1 & Estuaries and Coasts (1.563) & Estuaries and Coasts (1.563) \\
2 & Limnology \& Oceanography (3.287) & Estuarine Coastal and Shelf Science (1.733) \\
3 & Aquatic Botany (1.338) & Wetlands (1.109) \\
4 & Marine Ecology -Progress Series (2.286) & Journal of Coastal Research (0.665) \\
5 & Oceanography and Marine Biology (3.444) & Journal of Experimental Marine Biology and Ecology (1.919) \\
6 & Estuarine Coastal and Shelf Science (1.733) & Harmful Algae (2.460) \\
7 & Bulletin of Marine Science (1.093) & Journal of Shellfish Research (0.875) \\
8 & Journal of Plankton Research (1.617) & Restoration Ecology (1.612) \\
9 & Fishery Bulletin-NOAA (1.403) & Marine Ecology-Progress Series (2.286) \\
10 & Biogeochemistry (2.536) & Limnology \& Oceanography (3.287)
\end{tabular}

$\mathrm{IF}_{2006}$ for each journal in parentheses. 


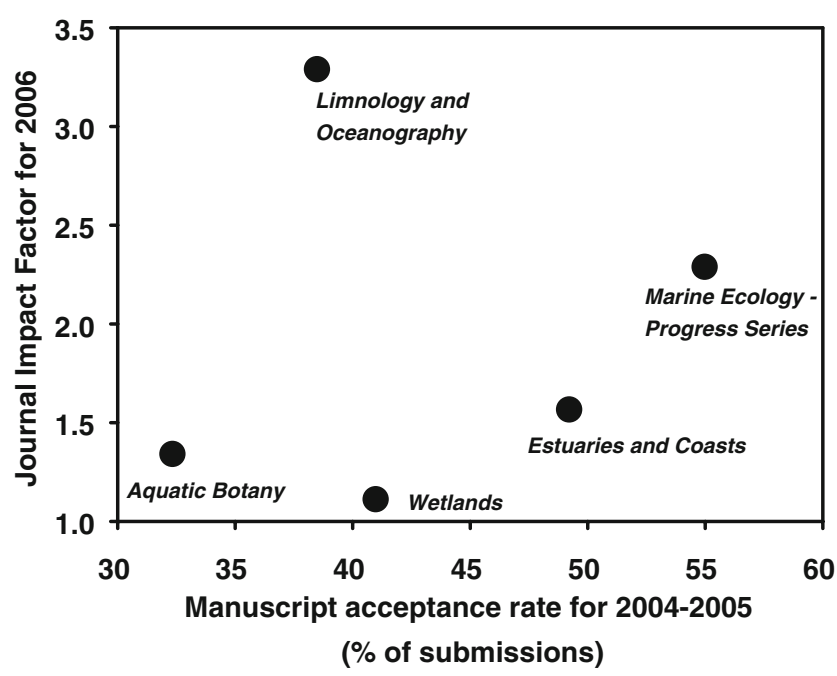

Fig. 4 Impact factor as a function of acceptance rates for Estuaries and Coasts and some of the most closely related journals. Acceptance rates were provided by the editorial offices of the related journals

cited was $3.5 \%$, compared to an average of $20 \%$ of papers in the field of coastal biogeochemistry that were never cited (Gattuso et al. 2005).

While most indicators we analyzed point to a vibrant and healthy journal, the data presented here also identify significant weaknesses of the journal. The IF of Estuaries and Coasts falls below the mean of the IFs of the ten journals that are most cited in Estuaries and Coasts papers and the mean of the ten journals most often cited by Estuaries and Coasts papers (Table 6). While the IF is acknowledged to be an incomplete metric of all facets of the quality of a scientific journal(Turner 1994; Bordons et al. 2002), papers appearing in Estuaries and Coasts are not cited as much, on average, as papers in many other related journals within the first 2 years of publication. Recent actions designed to advertise the broad scope of the journal, reach out to new estuarine and coastal scientists who have not traditionally published in Estuaries and Coasts, and ensure much greater electronic distribution of the journal should raise the profile of papers published therein and increase the visibility and stature (as well as the IF) of Estuaries and Coasts.

Fewer than $20 \%$ of the papers published in Estuaries and Coasts were written by scientists based at institutions outside the USA, despite the stated international scope of the journal. This figure is well below the contribution of countries outside the USA to the growth of knowledge and scholarly publication in the field, which was evaluated to be about $71 \%$ for the field of coastal biogeochemnistry (Gattuso et al. 2005). It is, however, comparable to the share of institutional subscribers of Estuaries and Coasts outside the USA (18.6\% in 2007). This suggests restricted distribution and availability of the journal as a prime reason for the meager number of contributions from the interna- tional scientific community to the papers published in Estuaries and Coasts. There may be, however, additional reasons. One reason may lay in a very restrictive interpretation of the term "estuaries," the sole word in the title of the journal for many years, in much of the world. Outside the USA, "estuary" is widely interpreted as applying only to drowned river valleys where freshwater is diluted with salt water. While this type of coastal ecosystem dominates the east coast of the USA, the cradle of the journal, they do not represent dominant features of the coastline in other parts of the world or even elsewhere in the USA.

These issues have now been addressed by the CERF, which owns the journal, and the journal Co-Editors-inChief through a series of actions aimed at increasing the visibility and availability of the journal as well as to remove barriers that may detract prospective authors from submitting relevant manuscripts to the journal. The first such action was a vote by the Governing Board of the Estuarine Research Federation to change the journal name from Estuaries to the more encompassing Estuaries and Coasts, which better reflects the journal scope, which states that "the coastal zone refers to the interface between land and ocean, and is broadly defined to include areas within estuaries, lagoons, wetlands, tidal rivers, watersheds that include estuaries, and adjacent coastal and shelf waters." This change was effective in 2006 and was followed by a change in the Federation's name, from the Estuarine Research Federation to the Coastal and Estuarine Research Federation, in 2008. In addition, the Board voted in 2003 to open without restriction the journal contents 5 years and older, thereby increasing the availability of journal contents. Moreover, the journal editors introduced two new sections in 2005, the Odum Synthesis Essay, published annually, and Perspectives in Estuarine and Coastal Science, that are provided, along with published papers winning CERF

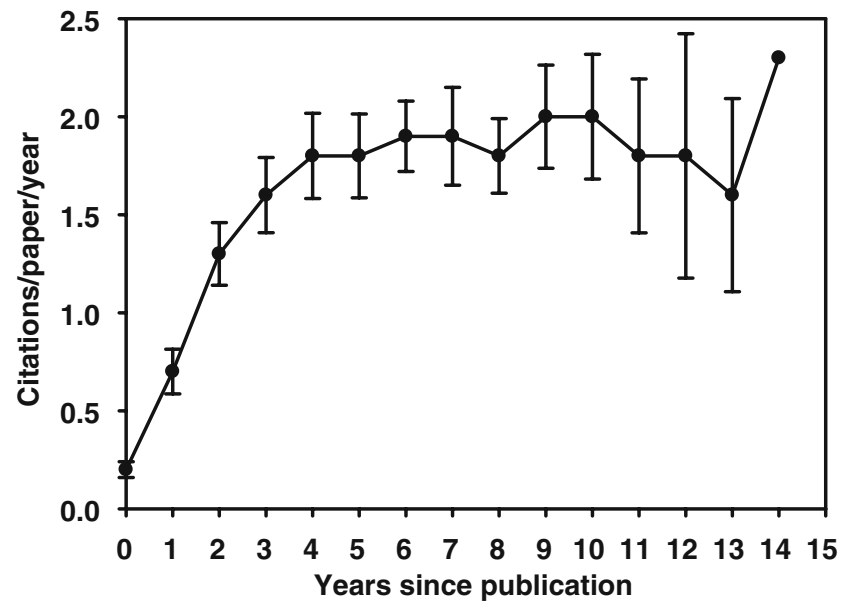

Fig. 5 Citation rate as a function of the age of papers appearing in Estuaries and Coasts, calculated from 1992-2005 data from the ISI Web of Science. Error bars \pm 1 standard error 
awards, in open-access form at publication. More substantially, the Board realized that the institutions subscribing to the journal and, hence, the potential readership of the journal was only a small fraction of the potential target. To achieve the broader distribution possible, the Board decided to co-publish the journal with Springer (cf. http://www. springer.com/west/home/environment?SGWID=4-198-70173750713-0). Estuaries and Coasts is now available at 25,000 institutions, up significantly from the ca. 500 institutional subscribers when the Federation published the journal on its own. We trust that these decisions will greatly enhance the availability and dissemination of the journal contents, thereby engaging a broader, more diverse community of readers as well as prospective authors. To further strengthen the journal, the Board has also recruited a new co-Editor-in-Chief, Dr. James E. Cloern, who will add, through his scientific skills and reputation, to the efforts to render this journal the outlet of choice for the best research on all aspects of estuarine and coastal systems. The roles of the co-Editors-in-Chief have been expanded as of the 2008 volume to include responsibility for decisions relating to acceptance of submitted papers. Together, the co-Editorsin-Chief have raised the international membership of the editorial board to encompass one third of the associate editors in 2008, one more step to increase the international dimension of the journal.

These changes are already delivering improvements, such as the promising increase in the IF in 2006 (from 1.284 in 2005 to 1.563 in 2006), the steepest in the journal's history. While encouraging, Estuaries and Coasts still has substantial room for improvement to rank among the top journals in the field by this metric, which will require actions to expand the readership and scope of the journal and its international dimension. Future editorial actions must consider that the face of scientific publication is rapidly changing. The classic printed journals that those of us of a certain age have lined up on our shelves are already on their way out. The current state of affairs is a rendering of those paper magazine style journals in an electronic format; we can only assume that this is an unstable condition that will soon give way to a format that more fully utilizes the capabilities of an internet-based electronic production and distribution system. If Estuaries and Coasts is to continue its trajectory as an outlet of increasing scientific relevance, it will take the continued efforts of the faithful pool of authors to submit their best work to the journal, as well as a constant reappraisal of editorial and production policies by the editorial board of the journal. We are confident that by working together as the community that is the Coastal and Estuarine Research Federation, we can assure the continued rise we have witnessed from the inception of Chesapeake Science through the current Estuaries and Coasts to foster the growth of coastal and estuarine science through the twentyfirst century.

Acknowledgments The bibliometric analysis presented here was supported by the Governing Board of the Estuarine Research Federation. We thank Everett Fee, Editor-in-Chief of Limnology and Oceanography; Jan Vermaat, co-Editor-in-Chief of Aquatic Botany; Darold Batzer, Editor-in-Chief of Wetlands; and Matthias Seaman, assistant Editor-in-Chief of Marine Ecology-Progress Series, for providing data on manuscript acceptance rates at their journals. We thank Allen Press for data on Estuaries subscribers. James E. Cloern, Joy Bartholomew, Matthias Seaman, and two anonymous reviewers provided thoughtful comments on this paper. This is contribution \#381 of the Southeast Environmental Research Center at Florida International University.

\section{References}

Bordons, M., M.T. Fernández, and I. Gómez. 2002. Advantages and limitations in the use of impact factor measures for the assessment of research performance in a peripheral country. Scientometrics 53: 195-206.

Cronin, L.E. 1960. Introduction. Chesapeake Science 1: 1.

Gattuso, J.P., N.A. Dawson, C.M. Duarte, and J.J. Middelburg. 2005. Patterns of publication effort in coastal biogeochemistry: a bibliometric survey (1971-2003). Marine Ecology Progress Series 294: 9-22.

Sacco, W.P., and S. Milana. 1984. Increase in number of authors per article in 10 APA journals: 1960-1980. Cognitive Therapy and Research 8: 77-84.

Threlkeld, S.T. 2006. Editorial: Announcing Estuaries and Coasts, journal of the Estuarine Research Federation. Estuaries and Coasts 29: $1-3$.

Turner, R.E. 1994. Comparisons of estuarine and coastal journal quality. Estuaries 173: 721-725.

Valiela, I., K. Foreman, M. LaMontagne, D. Hersh, J. Costa, P. Peckol, B. Demeo-Anderson, C. D'Avanzo, M. Babione, C.-H. Sham, J. Brawley, and K. Lajtha. 1992. Couplings of watersheds and coastal waters: Sources and consequences of nutrient enrichment in Waquoit Bay, Massachusetts. Estuaries 154: 443-457.

Wiley, M.L. 1978. Editorial: Announcing Estuaries, journal of the Estuarine Research Federation. Estuaries 1: i.

Zetterstrom, R. 2004. The numbers of authors of scientific publications. Acta Paediatrica 93: 581-582. 